\title{
Validation Measurement Model of Emotional Intelligence among Technical Teachers in Vocational Colleges Ministry of Education Malaysia
}

\author{
Mohamad Zaid Mustafa; Yahya Buntat; Zainal Abidin Sayadi; Abdul Rasid Abdul Razzaq; Rosnee Ahad \\ University Tun Hussein Onn Malaysia, \\ Johore, Malaysia \\ University Technology Malaysia,
}

\begin{abstract}
This study is to validate the emotional intelligence construct measurement model on technical teachers from vocational colleges under the Ministry of Education, Malaysia. 493 samples from 25 vocational colleges comprising technical teachers specialising in electrical and electronic engineering, civil engineering as well as mechanical engineering acted as the respondents in this study. Data were analysed using Structural Equation Modeling (SEM) AMOS 20 software. An exploratory factor analysis was done on the Goleman's (1998) emotional intelligence 72 item inventory and only 51 items remained for further analysis. To validate the construct measurement model, three aspects were examined; (i) unidimensionality (loading factor value $\geq 0.6$ ), (ii) validity (convergent validity AVE $\geq 0.5$, and construct validity referring to fitness indexes), and (iii) Reliability (composite reliability, $\mathrm{CR} \geq 0.6$ and Average Variance Extracted $\geq 0.5$ ). After 3 more items were dropped, the remaining items were reanalyzed. The findings revealed that all the 48 items recorded loading factor value $>0.6, \mathrm{AVE} \geq 0.5$, fitness indexesfor Absolute Fit (RMESA=0.053), Incremental Fit $(\mathrm{CFI}=0.908$, TLI $=0.903)$, Parsimonious Fit $(C h i s q / d f=2.380)$ and $C R \geq 0.6$. It can be concluded that with the 3 items dropped (loading factor $<0.6$ ), the modified measurement model was fit to be used for structural model analysis.
\end{abstract}

Keywords: emotional intelligence

\section{INTRODUCTION}

Vocational Education Transformation Plan, launched in 2011, has brought tremendous changes towards vocational schools. The status of 71 vocational secondary schools have been upgraded into Vocational Colleges (MOE, 2011). With the change in status, aspects such as the curriculum and extra curriculum structure, working hours, enrolment system, infrastructre and facilities, human resource, and administration, just to name a few, also require some reassessment (BPTV, 2012) [1]. The transformation of vocational colleges involved administrative staff as well the teachers. However, based on observations and interviews with the directors and technical teachers from ten vocational colleges, it was found that the technical teachers were more affected compared to the administrative staff. The change in the curriculum enables the students to be awarded with the Malaysian Skills Certification (SKM), and this means that the teachers' teaching load also increased. This view is parallelled with the view by Stasz et. al.,(2004) [2] who state that the type and depth of technical education programme depends on thelevel of skills targeted. To deliver high quality technical education with effective teaching and learning process, the education system requires high quality and committed teachers and leaders (Barber \& Mourshed, 2007) [3]

Most of the times, teaching and learning sessions involved laboratory works. However, unlike other science subjects, these technical teachers are not assisted by lab assistants (Sharifah et al., 2013) [4]. In addtion, according to Azarudin (2004) [5], these teachers are also tasked with other responsibilities such as class teacher, subject coordinator and extra curricular activities. These teachers are also required to manage the inventory and storage of lab equipment, $5 \mathrm{~S}$ as well as the cleanliness of the lab. These chores indirectly affect the teachers' job satisfaction (Azaruddin, 2004) [5]. Boateng (2012) [6] believes the characteristics of technical eduation present a unique challenge to the administration and organisation; these technical institutions require laboratories, equipment, facilities and raw materials, and inevitably, causing the teachers' work load to increase.

Apart from that, compared with the normal education system, technical education is more complicated (Boateng, 2012) [6] as it requires more time for teaching preparation and lab work. The way students are assessed on their skill competencies is also different compared to the assessment done in the normal education system. Sanderson et al., (2000) [7] also state that technical teachers possess skills that other academic teachers do not have and this makes them to have better opportunities to get involve in business and industries that offer them better income. In a survey carried out in the United States of America, it was revealed that $41.3 \%$ of the technical education teachers have the intention to leave for other more lucrative professions (Sanderson et al., 2000) [7].

According to Goleman (1998) [8], a person's success is not only determined by his intelligence quotient (IQ) but emotional quotient (EQ) too. Goleman suggests that $20 \%$ of success is contributed by IQ while another $80 \%$ is due to EQ. Thus, high IQ must be balanced by high EQ. EQ involves the ability to recognise one's as well as others' feelings, the ability 
to self motivate and positive internal emotion and in relationship with others. Studies have shown that EQ plays a very important role in ensuring career success (Shahril 2000; Mayer \& Caruso 2000; Mayer, Salovey, \& Caruso 2000; Goleman 1995, 1999) [9][10][11][12][13]. Ruisel (1992) [14] links EQ with the concept of social quotient (SQ). EQ refers to how the brain functions under different conditions caused by feelings and emotions (Hyo Sun Jung \& Hye Hyun Yoon. 2012) [15]. Hyo Sun Jung and Hye Hyun Yoon also suggest that having good EQ will help a person to be a better worker as well in their daily life.

Mayer dan Salovey (1997) [16] state that EQ is one's ability to identify and control his emotions that lead to desired behavior and action. Goleman (1998)[8], on the other hand, defines EQ as the ability to manage his own emotions as well as others in the aspects of feelings, emotions and behaviours. Cooper and Sawaf (1997) [17] define EQ as the ability to sense, understand and apply the power of emotions as a source for motivation, information, relationship and influence. BarOn (2005) uses the term emotional-social intelligence (EI) instead of EQ. EI is a combination of social, personal and emotional skills that influence one's ability to effectively and actively adapt to the surroundings and stress. Nelson dan Low (2003) [18] view EQ from another perspective. For them, EQ is the combination of skills and abilities to identify themselves, self respect amd willing to be responsible for being worthy and dignified.

According to Dulewicz and Higgs (2000) [19], emotional intelligence can be defined as understanding self-esteem and being able to handle the feelings without being influenced, capable of motivating themselves infulfilling tasks, creatively and strive to achieve maximum, sensitive to the feelings of others and to deal with social relationships effectively. According to Young (2001) [20] emotional intelligence refers to a subset of social intelligence. It is the ability of a person to examine emotions or feelings of himself or others and intelligently distinguish emotions and using the skills as a guide to think and shape the actions to be taken.

Based on the definitions given by some of these psychologists, it can be concluded that emotional intelligence is the individual's ability to recognise, understand and use the emotions of oneself and others to guide themselves in the right way to gain a balanced and prosperous life whether in terms of personal life or work. Three Emotional Intelligence Models discussed in the literature review are 1) Salovey dan Mayer Emotional Intelligence Model, 2) GolemanEmotional Intelligence Model, and 3) Bar-On Emotional Intelligence Model.

\section{Emotional Intelligence Models}

Salovey \& Mayer (1990) [21] have proposed 5 domains related to emotional intelligence; 1) recognising emotions, 2) managing emotions, 3) motivating negative emotions, 4) understanding emotionsof others, and 5) managing relationships. Salovey and Mayer's Inventory of Emotional Intelligence is divided into two categories: Schutte Emotional Intelligent Scale (SEIS) developed in 1990 and MayerSalovey-Caruso Emotional Intelligence Test (MSCEIT), developed in 2002. SEIS is a 33-item self-report measure ofemotional intelligence and is a widely used instrument in many studies (Dimitriades, 2007; Cakan \& Atun, 2005; Carmeli, 2003) [22][23][24]. The consistency in Alfa Cronbach is between $0.87-0.90$ and test reliability with a value of 0.78 (Zeng \& Miller, 2001)[25]. Mayer-Salovey-Caruso Emotional Intelligence Test (MSCEIT), on the other hand, was designed by Mayer, Salovey and Caruso in 2002. Previously known as the Multifactor Emotional Intelligence Scale (MEIS), MSCEITis also based on the theory that Mayer and Salovey (1997) [16] proposed. MSCEIT is an objective measure of emotional intelligence identifying on emotional perceptions, understand emotions, emotional integration and emotional regulation. This measurement method contains 141 items and takes between 30-45 minutes to complete,covers four branches of emotional intelligence. The Cronbach Alpha value is between 0.76 and 0.93 (Zeng \& Miller, 2001) [25] and the test- reliability value is 0.86 (Mayer, Salovey \& Caruso, 2000) [26].

Goleman's Emotional Intelligence Model (1995) has expanded the concept of emotional intelligence around the world with the theory that emotional intelligence is a spiritual aspect that needs to be given priority in all aspects of life, especially in working situations. In addition, he also states emotional intelligence as the ability to control emotional impulses or emotions, ability to identify complex hidden emotions, and the ability to handle smooth relationships. The studies conducted by Goleman (1995) [12] found that the human mind topography has two components; the first component is a rational mind which is a conscious mode of awareness (consciousness, thinking, reflection and remembering), while the second component is the emotional mind. According to him, the emotional mind provides information for rational minds operating and rational minds refine it and sometimes shape the emotional outcome. The balance will result in one of the rational minds and cause one to act according to the feelings, an irrational mind.

Goleman (1995) [12] emphasises that every individual needs to have emotional intelligence. This is because, according to Goleman, there are many intellectually intelligent individuals who are unhappy in their lives due to failure in interpersonal relationships. In 1995, Goleman proposed five emotional intelligence domains which are said to be a solid foundation in building the definition of emotional intelligence. The five domains are 1) recognising self-emotions, 2) managing self-emotions, 3) motivating self emotions, 4) empathy, and 5) social skills (Goleman, 1995) [12]. Goleman'semotional intelligence model is guided by the theory of achievement, where this model is broad-based and the measurement of emotional intelligence involves both independent reports and others (Boyatzis \& Burckle, 1999).

A study by Boyatzis et al. (2000) [27] reveals that Goleman's emotional intelligence model was based on personality and social competencies. Goleman's model has introduced a measurement tool known as Emotional Competentcy Inventory (ECI) developed in 1999 and ESCI in 2002. Emotional Competency Inventory Version 2 (ECI 2.0) 
wasdeveloped to replace Emotional Competency Inventory (ECI) (Boyatzis, Goleman, \& Rhee, 2000) [27]. ECI 2.0 has 72 items. These items measure 18 competencies compiled under four dimensions; (1) emotional self-awareness (selfassessment, and self-confidence), (2) Self-management (selfregulation of emotion, transparency, adaptability, optimism, achievement orientation, and initiative). (3) social awareness (empathy, service orientation, and organizational awareness), and (4) Relationship management (developing others, inspired leadership, catalysts of change, influence, conflict management, and teamwork)(Wolff, 2005) [28]. The internal consistency of ESCI for Alfa Cronbach as a whole is 0.63 (Wolff, 2005; Jonker \& Vosloo, 2008)[28][29].

The Bar-On Emotional Intelligence Model,founded by Reuven Bar-On in 1985, encompasses five dimensions of intrapersonal, interpersonal, adaptability, stress management and general mood. Bar-On EQ-i (1997) was developed by Bar-On, a psychologist who studied emotional intelligence for over 17 years. This method of measurement has been used to evaluate thousands of individuals for over a decade due to the reliability and validity of the results obtained. Measurement methods in the form of self-report are based on responses of respondents aged 17 years and over and take 40 minutes to complete. This EQ-i instrument covers 133 items in short form and uses 5-point likert scale covering 5 basic scales and 15 sub-scales. According to Bar On (1997), the EQ-i instrument has been applied to correction factors that can automatically adjust scale scores based on the two instrument indices that can further improve measurement accuracy. In this study, researchers used the ECI 2.0 inventory developed by Goleman (2002), there are 72 items listed in ECI 2.0 which are divided into 4 dimensions or clusters. This inventory has been adopted by Noorhafeza Herliani Adey and Ferlis Bahari (2010) [30]. In the early stages of the study, the EFA analysis was done with a sample of 200 people, the findings have reduced the number of items from 72 items to 51 items. Overall, it can be concluded that these three models of emotional intelligence are very popular and are always referred to in earlier studies.

\section{METHODOLOGY}

In this study, Structural Equation Modeling (SEM) and Analysis of Moment Structures (AMOS) software were used in analysing and verifying the proposed model at the prefeasibility stage. This approach has been widely used in several disciplines, including banking, healthcare, information management, logistics, marketing, psychology, and tourism management (Lu et al., 2007) [31]. Out of 865 questionnaires distributed, 609 were returned to the researchers. 23 questionnaires were found to be incomplete and thus removed. Therefore, only 586 questionnaires were analysed.

\section{Outlier Data}

Data from the 586 completed questionnaires were keyed in into SPSS version 20 and subsequently AMOS version 21 . The outlier data detection was performed by observing the furthest value from the centre (Mahalanobis Distance) (Iman Ghozali, 2008; Tabachnick and Fidell, 2007) [32][33]. The criterion used is based on the value of the Chi-squares Distribution Table at the degree of fredom, the number of construct items at the significant level of $p<0.001$ as suggested by Tabachnick and Fidell (2001)[33]. The value of Mahalanobis Distance in this study is $\mathrm{x} 2=143.344$, df $=95, \mathrm{p}$ $<0.001)$. Data with Mahalanobis Distance value greater than 143.3.44 are considered as outlier data and discarded from the analysis. Considering this, 493 sets of data are desirable to be analyzed. The remaining sample sizes still meet the criteria of the minimum sample size survey as proposed by Hair et al. (2006) [34].

\section{Normality Test}

After the isolation process,normality tests using the skewness and kurtosis method were carriedout (Hishamuddin, 2005 \& Zainudin, 2012) [35][36]. Data are normally distributed if the skewness and kurtosis values are within the range of \pm 1 (Zainudin, 2012; Mayer et al., 2006; Hishamuddin, 2005; George \& Mallery, 2003) [36][35]. According to Zainudin (2015) [37], if the sample exceeds 200 skewness, kurtosis values can be up to \pm 1.5 . Tabachnick and Fidell (2007), on the other hand, suggest data normality based on skewness and kurtosis values at \pm 2 range for large samples. This study adopted Tabachnick and Fidell's (2007) suggestion. The normality test done shows that all values are within the permissible range.

\section{FINDINGS}

Comfirmatory factorial analysis (CFA) was conducted to validate the emotional intelligence measurement model among electrical and electronics engineering, civil engineering and mechanical engineering technical teachers at Vocational College, Ministry of Education, Malaysia. To ensure this measurement model can be used, three criteria were considered; 1) Unidimensionality (loading factor $\geq 0.6$ ), 2) Validity (convergent validity $\mathrm{AVE} \geq 0.5$, construct validity refering to fitness indexes and discriminant validity) and 3) Reliability (composite reliability, $\mathrm{CR} \geq 0.6$ and Average Variance Extracted $\geq 0.5$ ) (Zainudin, 2015). According to Zainudin (2015), discriminant validity is only calculated for the combined model involving the main constructs only. Composite Reliability (CR) and Average Variance Extracted (AVE) are calculated using the formula, $\mathrm{CR}=\left(\sum \mathrm{K}\right)^{2} /\left[\left(\sum \mathrm{K}\right.\right.$ )$\left.^{2}+\left(\sum 1-\mathrm{K}^{2}\right)\right]$ and AVE $=\sum \mathrm{K}^{2} / \mathrm{n}$ where $\mathrm{K}$ is the loading factor of each item and $n$ is the number of items in the measurement model.

Fitness Index measurement model is based on (i) The Root Mean Square of Error Approximation, RMSE $\leq 0.008$, (ii) Incremental Fit Index, IFI $\geq 0.9$, (iii) Comparative of Fit Index, CFI $\geq 0.9$, (iv) Tucker Lewis Index, TLI $\geq 0.9$, and (v) Chi Square / Degress of Fredom, Chisq/df $\leq 3.0$. If the analyzed model does not match, Zainudin (2015) [37] and Hair et al., (2006) [34] recommend that modifications to the model be performed by checking the loading factor for each item to exceed 0.6.Itemswith loading factor less than 0.6 should be dropped, and if the match index has not been 
reached revision to the modification index (MI) Based on MI $\geq 15$, the item needs to be relooped.

ConfirmatoryFactor Analysis (CFA) was performed to validate the emotional intelligence instruments based on 4 constructs and 11 sub-constructs. The purpose of this analysis is to examine the validity of emotional intelligence measurement model which has 51 items. To ensure the measurement model developed is unidimensional, all items that measure the constructs or sub construct should be $\geq 0.6$ and any item $\leq 0.6$ should be dropped from the model. Figure 1 shows the loading factor for all items for the construct of emotional intelligence.

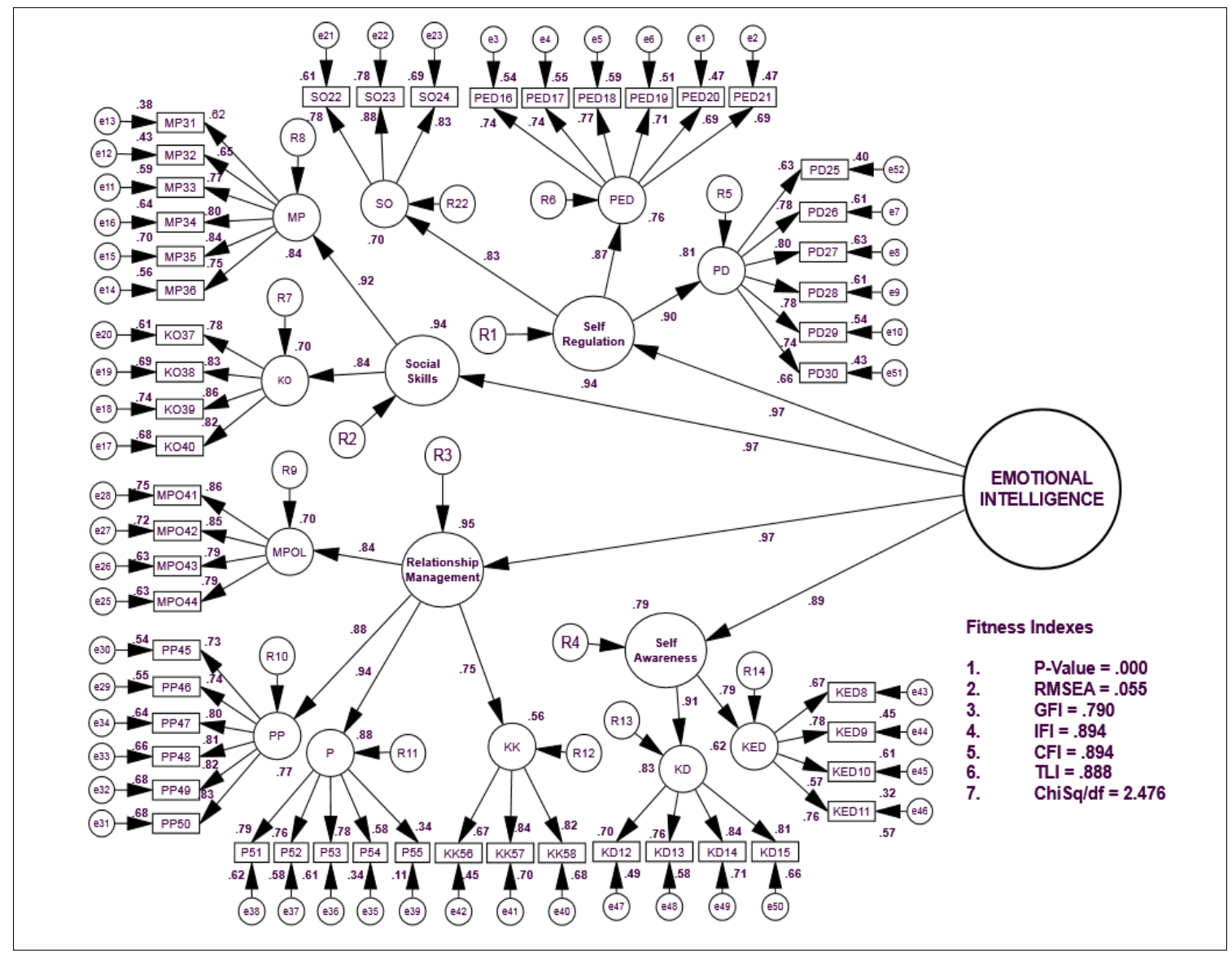

Figure 1: Emotinal Intelligence Measurement Model

The results show that 3 items, KED10, P55 and P54, recorded loading factor $<0.6$ and thus, need to be dropped. When re-analysed, the remaining items recorded loading factor value of $\geq 0.6$, indicating that the model had achieved unidimension as shown in Figure 2.

\section{Validity}

To ensure that this model is valid, the construct validity, convergent validity and discriminate validity need to be performed. Construct validity will be fulfilled when the fitness indexs are according to the conditions set. Figure 2 shows the compatibility index of the modified model having the value of RMSEA $=0.053$, CFI $=0.910$ and Chisq $/ \mathrm{df}=2.380$, all of these values have fulfilled the prescribed minimum requirements. The summary of compatibility index is presented in Table 1. 


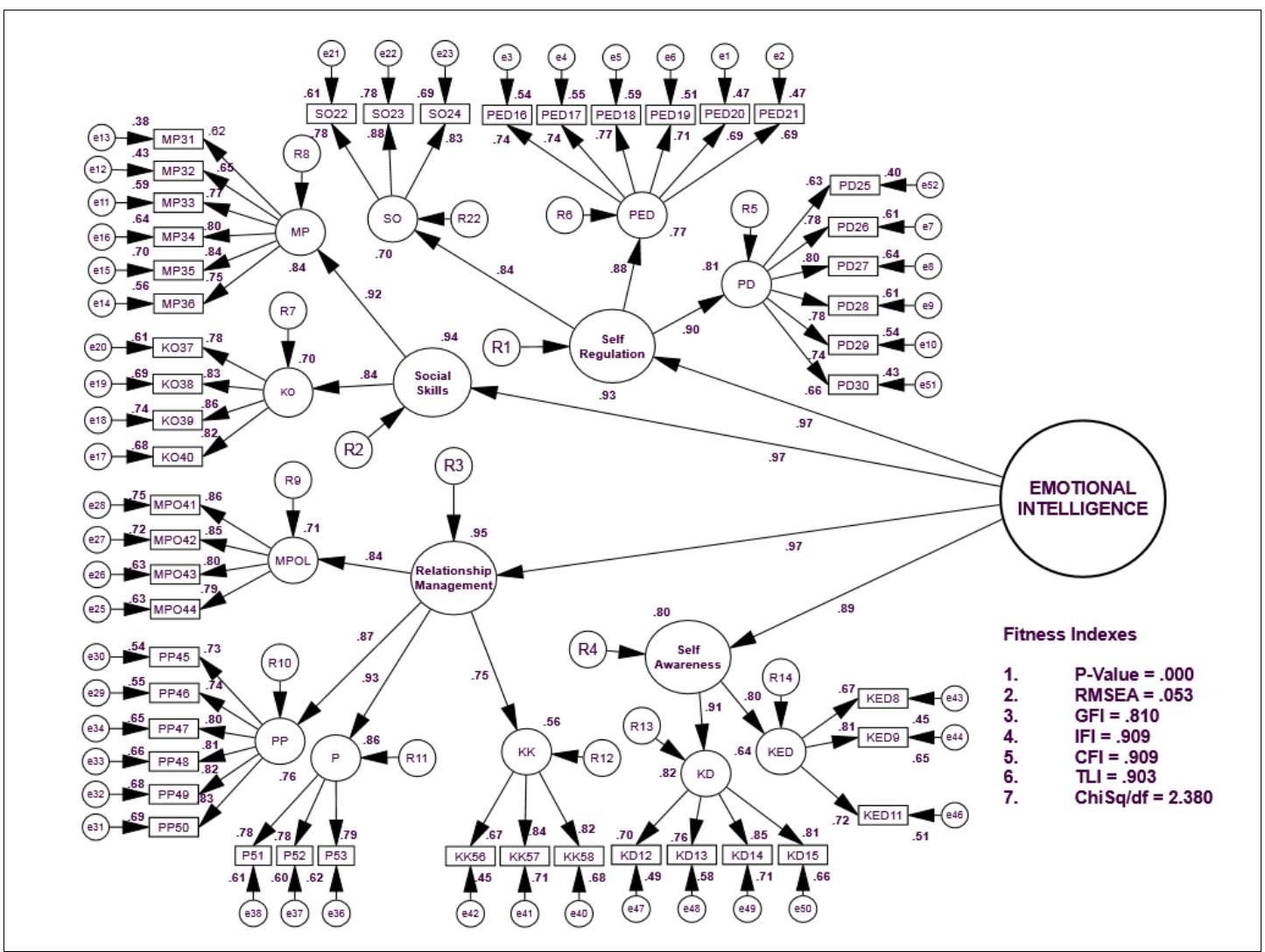

Figure 2 : Revised Emotional Intelligence Measurement Model (Items KED10, P55 and P54 dropped)

TABLE1: Summary ofFitness Indexesfor Emotional Intelligence Constructs (Zainuddin, 2015) [37]

\begin{tabular}{|c|c|c|c|l|}
\hline \multicolumn{1}{|c|}{ Category } & Index & $\begin{array}{c}\text { Hypothesised Index } \\
\text { Value }\end{array}$ & Modified Index Value & \multicolumn{1}{|c|}{ Level of Acceptance } \\
\hline \multirow{2}{*}{ 1. Absolute Fit } & RMSEA & 0.055 & 0.053 & RMSEA $\leq 0.08$ (Browne \& Cudek, 1993) \\
\cline { 2 - 5 } & GFI & 0.790 & 0.809 & GFI $\geq 0.09$ (Joreskog \& Sorbom, 1984) \\
\hline \multirow{2}{*}{ 2. Incremental Fit } & CFI & 0.894 & 0.908 & CFI $\geq 0.09$ (Bentler, 1990) \\
\cline { 2 - 5 } & TLI & 0.888 & 0.903 & TLI $\geq 0.09$ (Bentler \& Bonett, 1980) \\
\hline 3. Parsimonious Fit & Chisq/df & 2.476 & 2.380 & Chisq/df $\leq 3.00$ (Marsh \& Hocevar, 1985) \\
\hline
\end{tabular}

To meet the second validity requirement, convergent validity is measured by calculating the Average Variance Extracted (AVE) for all constructs and sub-constructs, where the required AVE value is $\geq 0.5$. Table 2 shows that the AVE value for emotional intelligence constructs recorded a value of 0.903. Table 3 , on the other hand, presents the construct values for self-management, social awareness, relationship management and self-awareness. The values recorded were $0.763,0.767,0.726$ and 0.734 , respectively. The AVE values for self-adjustment construct (0.539), self-emotion control (0.529), optimistic attitude (0.696), service orientation (0.551), organizational awareness (0.685), develop potential of others (0.674), catalyst change (0.682), influence (0.603), group collaboration (0.609), self-emotion awareness (0.537) and self-confidence (0.602) are all presented in Table 4.

\section{Reliability}

Composite Realibility (CR) test is conducted to ensure the reliability of construct items. The findings from the calculation show that $\mathrm{CR}$ for the construct of emotional intelligence is 0.974 , as summarized in Table 2. Table 3 shows the CR values for self-management construct sub (0.906), social awareness (0.868), relationship management (0.913) and self-awareness (0.846). CR values for the sub adjustment construct (0.875), self-regulation (0.871), optimistic attitude (0.873), serviceoriented (0.879), organizational awareness (0.897), develop the potential of others (0.892), catalyst change $(0.895)$, influence $(0.820)$, group collaboration $(0.822)$, self-emotion awareness $(0.775)$ and self-esteem $(0.862)$ are all summarised in Table 4. All these values recorded $\mathrm{CR} \geq 0.6$ 
indicating all the constructs have achieved the reliability test and internal consistency.

TABLE 2. Composite Reliability (CR) and Average Variance Extracted (AVE) forthird order emotional intelligence constructs

\begin{tabular}{|c|c|c|c|c|}
\hline Construct & Item & LoadingFactor & CR ( $\geq \mathbf{0 . 6})$ & \multirow{3}{*}{ AVE $(\geq \mathbf{0 . 5})$} \\
\hline \multirow{3}{*}{ EMOTIONAL } & Self Management & 0.96 & \multirow{2}{*}{0.974} \\
\cline { 2 - 3 } INTELLIGENCE & Social Awareness & 0.97 & \\
\cline { 2 - 3 } & Relatioship Management & 0.97 & & \\
\cline { 2 - 3 } & Self Awareness & 0.90 & & \\
\hline
\end{tabular}

TABLE 3. Composite Reliability (CR) and Average Variance Extracted (AVE) forsecond order emotional intelligence constructs

\begin{tabular}{|c|c|c|c|c|}
\hline Sub Construct & Item & LoadingFactor & $\mathrm{CR}(\geq 0.6)$ & $\operatorname{AVE}(\geq 0.5)$ \\
\hline \multirow{3}{*}{ Self Management } & PD & 0.90 & \multirow{3}{*}{0.906} & \multirow{3}{*}{0.763} \\
\hline & PED & 0.84 & & \\
\hline & SO & 0.84 & & \\
\hline \multirow{2}{*}{ Social Awareness } & MP & 0.91 & \multirow{2}{*}{0.868} & \multirow{2}{*}{0.767} \\
\hline & $\mathrm{KO}$ & 0.84 & & \\
\hline \multirow{4}{*}{ Relationship Management } & MPOL & 0.84 & \multirow{4}{*}{0.913} & \multirow{4}{*}{0.726} \\
\hline & PP & 0.87 & & \\
\hline & PPK & 0.93 & & \\
\hline & KK & 0.76 & & \\
\hline \multirow{2}{*}{ Self Awareness } & $\mathrm{KD}$ & 0.91 & \multirow{2}{*}{0.846} & \multirow{2}{*}{0.734} \\
\hline & KED & 0.80 & & \\
\hline
\end{tabular}

TABLE 4. Composite Reliability (CR) and Average Variance Extracted (AVE) forfirst order emotional intelligence constructs

\begin{tabular}{|c|c|c|c|c|c|}
\hline Sub Construct & Sub Sub Construct & Item & LoadingFactor & $\mathrm{CR}(\geq 0.6)$ & $\operatorname{AVE}(\geq 0.5)$ \\
\hline \multirow{15}{*}{ Self Management } & \multirow{6}{*}{$\begin{array}{c}\text { PD } \\
\text { (Self Adjustment) }\end{array}$} & PD25 & 0.63 & \multirow{6}{*}{0.875} & \multirow{6}{*}{0.539} \\
\hline & & PD26 & 0.78 & & \\
\hline & & PD27 & 0.80 & & \\
\hline & & PD28 & 0.78 & & \\
\hline & & PD29 & 0.74 & & \\
\hline & & PD30 & 0.66 & & \\
\hline & \multirow{6}{*}{$\begin{array}{c}\text { PED } \\
\text { (Self Regulation) }\end{array}$} & PED16 & 0.74 & \multirow{6}{*}{0.871} & \multirow{6}{*}{0.524} \\
\hline & & PED17 & 0.75 & & \\
\hline & & PED18 & 0.77 & & \\
\hline & & PED19 & 0.72 & & \\
\hline & & PED20 & 0.69 & & \\
\hline & & PED21 & 0.69 & & \\
\hline & \multirow{3}{*}{$\begin{array}{c}\text { SO } \\
\text { (Optimism) }\end{array}$} & $\mathrm{SO} 22$ & 0.79 & \multirow{3}{*}{0.873} & \multirow{3}{*}{0.691} \\
\hline & & SO23 & 0.88 & & \\
\hline & & SO24 & 0.83 & & \\
\hline \multirow{10}{*}{ Social Awareness } & \multirow{6}{*}{$\begin{array}{c}\text { MP } \\
\text { (Service Orientation) }\end{array}$} & MP31 & 0.62 & \multirow{6}{*}{0.879} & \multirow{6}{*}{0.551} \\
\hline & & MP32 & 0.65 & & \\
\hline & & MP33 & 0.77 & & \\
\hline & & MP34 & 0.80 & & \\
\hline & & MP35 & 0.84 & & \\
\hline & & MP36 & 0.75 & & \\
\hline & \multirow{4}{*}{$\begin{array}{c}\text { KO } \\
\text { (Organisational Awareness) }\end{array}$} & KO37 & 0.79 & \multirow{4}{*}{0.897} & \multirow{4}{*}{0.670} \\
\hline & & KO38 & 0.83 & & \\
\hline & & KO39 & 0.86 & & \\
\hline & & KO40 & 0.83 & & \\
\hline \multirow{4}{*}{$\begin{array}{l}\text { Relationship } \\
\text { Management }\end{array}$} & \multirow{4}{*}{$\begin{array}{l}\text { MPOL (Developing Potential } \\
\text { of Others) }\end{array}$} & MPO41 & 0.86 & \multirow{4}{*}{0.892} & \multirow{4}{*}{0.699} \\
\hline & & MPO42 & 0.85 & & \\
\hline & & MPO43 & 0.79 & & \\
\hline & & MPO44 & 0.78 & & \\
\hline
\end{tabular}




\begin{tabular}{|c|c|c|c|c|c|}
\hline Sub Construct & Sub Sub Construct & Item & LoadingFactor & $\mathrm{CR}(\geq 0.6)$ & $\operatorname{AVE}(\geq 0.5)$ \\
\hline & \multirow{6}{*}{$\begin{array}{c}\text { PP } \\
\text { (Catalyst Change) }\end{array}$} & PP45 & 0.73 & \multirow{6}{*}{0.895} & \multirow{6}{*}{0.682} \\
\hline & & PP46 & 0.74 & & \\
\hline & & PP47 & 0.80 & & \\
\hline & & PP48 & 0.81 & & \\
\hline & & PP49 & 0.82 & & \\
\hline & & PP50 & 0.83 & & \\
\hline & \multirow{5}{*}{$\begin{array}{c}\mathrm{P} \\
\text { (Influence) }\end{array}$} & P51 & 0.78 & \multirow{5}{*}{0.820} & \multirow{5}{*}{0.614} \\
\hline & & P52 & 0.77 & & \\
\hline & & P53 & 0.78 & & \\
\hline & & P54 & Deleted & & \\
\hline & & P55 & Deleted & & \\
\hline & \multirow{3}{*}{$\begin{array}{c}\text { KK } \\
\text { (Teamwork) }\end{array}$} & KK56 & 0.67 & \multirow{3}{*}{0.822} & \multirow{3}{*}{0.609} \\
\hline & & KK57 & 0.84 & & \\
\hline & & KK58 & 0.82 & & \\
\hline \multirow{8}{*}{ Self Awareness } & \multirow{4}{*}{$\begin{array}{c}\text { KED (Emotional Self } \\
\text { Awareness) }\end{array}$} & KED8 & 0.66 & \multirow{4}{*}{0.775} & \multirow{4}{*}{0.541} \\
\hline & & KED9 & 0.81 & & \\
\hline & & KED10 & Deleted & & \\
\hline & & KED11 & 0.72 & & \\
\hline & \multirow{4}{*}{$\begin{array}{c}\text { KD } \\
\text { (Self Confidence) }\end{array}$} & KD12 & 0.70 & \multirow{4}{*}{0.862} & \multirow{4}{*}{0.612} \\
\hline & & KD13 & 0.76 & & \\
\hline & & KD14 & 0.84 & & \\
\hline & & KD15 & 0.81 & & \\
\hline
\end{tabular}

\section{CONCLUSION}

586 questionnaires containing 51 items were analysed for the purpose of this study. Out of 51 items, 48 items were used as the basis for validating the measurement model. This measurement model can be verified by taking into account the value of 1) Unidimensionality (load factors $\geq 0.6$ ), 2) Validity (convergent validity $\mathrm{AVE} \geq 0.5$, construct validity, refering to fitness indexes and discriminant validity) and 3) Reliability (composite Reliability, $\mathrm{CR} \geq 0.6$ and Average Variance Extracted $\geq 0.5$ ). The findings show that all conditions have been fulfilled and thus the constructs were validated.

\section{REFERENCES}

[1] BPTV. (2012). Laporan Tahunan 2012; Bahagian Pendidikan Teknik dan Vokasional, Kementerian Pelajaran Malaysia.Diterbitkan oleh BPTV, KPM.

[2] Stasz, C. and Wright, S. (2004). Emerging policy for vocational learning in England. Will it lead to a better system? London: Learning and Skills Research Centre.

[3] Barber, M., \& M. Mourshed (2007). "How the World's Best Performing Schools Come out on Top." McKinsey \& Company, New York, USA.

[4] Sharifah Shafie, Suhaida Abdul Kadir\& Soaib Asimiran (2013). Beban Tugas Guru Kemahiran Hidup Bersepadu: Isu dan Cadangan, at 3rd Regional Conference on Educational Leadership and Management (RCELAM) 2013 on 19-21 November 2013 at Institut Aminuddin Baki, Genting Highlands, Malaysia.

[5] Azarudin (2004). Beban Tugas Guru Bengkel Dalam Pengurusan Bengkel Di Lima Buah SekolahMenengah Teknik Di Negeri Sembilan. Universiti Teknologi Malaysia.

[6] Boateng, C. (2012). Restructuring Vocational and Technical Education in Ghana: The Role of Leadership Development.International Journal of Humanities and Social Science Vol.2 No.4

[7] Sanderson, A., Phua, V. C., \& Herda, D. (2000). The American faculty poll. Chicago: National Opinion Research Center.

[8] Goleman, D. (1998). Working with Emocional Intelligence. $1^{\text {st }}$ Ed. London Bloomsbury Publishing.

[9] Shahril @ Charil Marzuki (2000). Ciri-ciri Kepimpinan Pengetua / Guru Besar Berkesan yang Dapat Mengahdapi Cabaran dan Harapan Pada
Abad ke 21, Jurnal Kepimpinan Pendidikan. Institut Aminudin Baki, Kementerian Pendidikan Malaysia, 10(2).

[10] Mayer, J.D dan Caruso, D.R. (2000). Emotional Intelligence at Zeitgeist, as Personality and as a Mental Ability.Dalam Bar-On, R. \& Paker, J.D.A. The Handbook of emotional intelligence: theory, development, assessment and application at home, school and in the workplace, pp 92-117. San Francisco: Jossey-Bass.

[11] Mayer, J.D., Salovey, P., \& Caruso, D.R. (2000). Mayer-Salovey-Caruso Emotional Intelligence Test (MSCEIT). Toronto, Canada: MultiHealthSystems, Inc

[12] Goleman, D. (1995). Emotional Intelligence. New York: Bantam Books.

[13] Goleman, D. (1999). Working Science For Results: With Emotional Intelligence. New York: Bantam Books.

[14] Ruisel, I. (1992). Social intelligence: Conception and methodological problems. Studia Psychologica, 34(4-5), 281-296.

[15] Hyo Sun Jung \& Hye Hyun Yoon (2012). The Effects of Emotional Intelligence on Counterproductive Work Behaviors and Organizational Citizen Behaviors among Food and Beverage Employees in A Deluxe Hotel. International Journal of Hospitality Management. 31: 369-378.

[16] Mayer, J.D., \& Salovey, P.(1997). What is Emotional Intelligence? Dalam Salovey, P. \& Sluyter, D.J. (Eds), Emotional Development and Emotional Intelligence : Education Implication (pp3-34). New York: Basic Books.

[17] Cooper, R.K. \& Sawaf, A. ( 1997). Executive EQ: Emotional Intelligence in Leadership and Organizations, New York: Grosseflutnam.

[18] Nelson, D. \& Low, G. (2003).Emotional Intelligence: Achieving Academic andCareer Excellence.Upper Saddle River, New Jersey: Prentice Hall.

[19] Dulewicz, V. \& Higgs, M. (2000), Emotional intelligence: A review and evaluation study, Journal of Managerial Psychology, Vol. 15, No. 4, pp. 341-372.

[20] Young, B. A. (2001-2002). Elementary and secondary education. Education Statistics Quarterly,5(2). 
[21] Salovey, P., \& Mayer, J.D. (1990).Emotional Intelligence, Cognition and Personality. 9:185-211.

[22] Dimitriades, Z.S. (2007). Managing emotionally intelligent service workers: Personal and positional effects in the Greek context. Journal of European Industrial Training, 31(3), 223-240.

[23] Cakan, M. \& Altun, S.A. (2005).Adaptation of an emotional intelligence scale for Turkish educators. International Education Journal, 6(3), 367-372.

[24] Carmeli, A. (2003). The relationship between emotional intelligence and work attitudes, behavior and outcomes.Journal of managerial psychology, 18,788813.

[25] Zeng, X., \& Miller, C. E. (2001). Examinations of Measurements of Emotional Intelligence. Ergometrika, 2, 38 - 49.

[26] Mayer, J.D., Salovey, P. dan Caruso, D.R. (2000). Emotional Intelligence . In R.J Sternberg (Ed). The Handbook of intelligence, halaman 396-420. New York: Cambridge University Press.

[27] Boyatzis, R. E., Goleman, D., \& Rhee, K. (2000). Clustering competence in emotionalintelligence: Insights from the Emotional Competence Inventory (ECI). BarOn,R. \& Parker, D. A. (Eds.), Handbook of Emotional Intelligence. San Francisco:Jossey-Bass.

[28] Wolff, S. B. (2005). Emotional competence inventory (ECI): Technical manual. Hay Group.
[29] Jonker, C. S., \& Vosloo, C. (2008).The psychometric properties of the Schutt e EmotionalIntelligence Scalehttp. Journal of Industrial Psychology, 34(2), 21-30.

[30] Noorhafeza Herliani Adey dan Ferlis Hj. Bahari (2010). Hubungan antara kecerdasan emosi, kepuasan kerja dan komitmen terhadap organisasi.Jurnal Kemanusiaan bil.16.

[31] Lu, C.S., Lai, K., Cheng, T., 2007. Application of structural equation modelling to evaluate the intention of shippers to use internet services in liner shipping. Eur. J. Oper. Res. 180, 845-867.

[32] Iman Ghozali (2008). Model Persamaan Struktural Konsep dan Aplikasi Dengan Program Amos 16.0. Penerbit Universitas Diponegoro Semarang, Indonnesia.

[33] Tabachnick, B. G., \& Fidell, L. S. (2007). Using multivariate statistics (5th ed.). Upper Saddle River, NJ: Pearson Allyn \& Bacon [34] Hair, Jr., J. F., Black, W. C., Babin, B. J., Anderson, R. E., \& Tatham, R. L. (2006). Multivariate data analysis (6th ed.). Uppersaddle River, New Jersey: Pearson Education International, Inc.

[35] Hishamuddin Md. Som (2005). Panduan Mudah Analisis Data Menggunakan SPSS Windows. Skudai, Johor : Universiti Teknologi Malaysia.

[36] Zainudin Awang (2012). Structural Equation Modeling Using AMOS Graphic. Shah Alam : UiTM Press.

[37] Zainudin Awang (2015). Structural Equation Modeling Using AMOS Graphic. Shah Alam : UiTM Press. 